\title{
A FÊNIX
}

Vanderney Lopes da Gama ${ }^{1}$

I

Desde há muito tempo ouvimos falar da crença que certos povos indígenas e até os mais remotos primitivos bárbaros possuíam. Eles pensavam que incorporavam maiores poderes e coragem a sua existência pelo simples fato de comerem seus inimigos derrotados e capturados.

Fato verídico ou não, a questão merece respeito e, em dias tão tempestuosos como os que vivemos, embora nossa racionalidade nos force a pensar o contrário, sempre aparece uma situação que nos faz refletir sobre nossos antigos ancestrais e seus comportamentos animalizados.

Sou um cientista conhecido e acreditado. Sofria de um problema nos rins que foi resolvido graças à doação de uma pessoa desconhecida. Tenho anos de profissão e tenho visto a ciência e a medicina andarem lado a lado com a tecnologia. Às vezes, vejo-me como num filme de

${ }^{1}$ Mestrando em Literatura Brasileira na Universidade Estadual do Rio de Janeiro. 
ficção, reinventando coisas e seres inacreditáveis a qualquer um que tenha vivido nos anos quinze do século XXI.

Os transplantes de órgãos são uma arma que salva muitas vidas nos dias atuais. Pena que ainda haja muita gente preconceituosa e mesquinha. Vão e levam tudo consigo... Mesmo que não valham o ar que respiram...

Vivo em um mundo moderno e repleto de problemas como o são os mundos de hoje em dia: se em 2009 as coisas estavam complicadas, quase cinquenta anos depois o mundo está mergulhado em escuridão e trevas. Pessoas vazias andam a procura de outras tanto quanto ou mais do que elas o são... e é por isso que penso: "talvez todos os acontecimentos que estou prestes a relatar sejam apenas impressões que julguei ter ocorrido de maneira diferente em um momento inoportuno. Na verdade, não sei se não havia percebido ainda ou se tudo sempre estivera guardado e adormecido em nós, esperando apenas o andar das coisas...

Tenho notado a cada dia a preocupação das autoridades com a violência e a criminalidade crescentes em nossa sociedade. Não sei se o lado negro ou ruim do homem está somente estampado nas páginas dos jornais e nas imagens dos telejornais ou se, na verdade, há uma outra escuridão maior... um outro lado sombrio... Comum a todo ser... Seja ele marginalizado ou não! Tenha ele religião ou não... Enfim, seja ele quem for!

Posso dizer com quase total certeza que tudo começou a mudar quando um certo homem das leis teve uma tremenda e aparente 
belíssima ideia. Como já disse, os dias são tumultuados e perigosos e, pensando nisso, esse legislador bolou uma maneira eficaz de diminuir a criminalidade e a violência urbanas.

O projeto foi observado por muitos homens da casa legislativa e depois de alguns meses de discussões acabou passando pelo crivo de todos e virou lei. Lei esta que mudaria para sempre os dias de minha vida e de pessoas que só conhecia na mesa de operações e depois julgava revê-las nos noticiários da televisão em situações que jamais imaginaria...

Com certeza você, caro colega, deve estar ansioso para saber que diabo de lei é esta. Não sei se Lúcifer tem alguma coisa a ver com ela, mas o fato é que coisas estranhas ocorreram depois de tal implantação. A lei aprovada dizia que todos os estupradores, assassinos, pedófilos e bandidos que ameaçassem a integridade da sociedade como um todo, ao morrer teriam automaticamente seus órgãos doados para os bancos de órgãos do país e lá eles seriam encaminhados para os estados que tivessem maior necessidade.

A ideia foi perfeita e acertou um tiro certeiro no problema dos transplantes. A única questão que criou polêmica até nos bastidores dos hospitais foi o fato de o paciente (somente o paciente) ficar sabendo quem estava doando o órgão para ele. No entanto, a família do doador jamais sabia quem recebia a nova vida.

É claro que as famílias dos meliantes irracionais gritaram, fizeram passeatas, algazarras; tocaram fogo nos transportes, prometeram até fazer greve de fome se tal lei fosse aprovada... Mas foi 
tudo em vão! Muitos morreram em combates ferozes e, claro, tiveram seus órgãos doados também... Depois, com o tempo, todos foram fingindo se acostumar com aquela ideia estranha, macabra e salvadora.

O tempo passou.

Cinco meses depois da implantação da lei, as ruas pareciam mais calmas. As pessoas pareciam caminhar mais confiantes pelas ruas e as familias pareciam mais felizes e alegres. Mas, embora a aparência fosse agradável e tudo parecesse como num conto de fadas feliz, havia uma leve suspeita no ar de algo que não sabíamos ao certo o que seria. Era como se todos os dias ao acordar sorríssemos pela vida renovada em nós e, ao mesmo tempo, desconfiássemos de uma mudança qualquer que não saberíamos explicar... Alguns chegaram a acreditar que vivíamos uma outra vida nesta vida!

Fomos vivendo e sentindo as expectativas dos acontecimentos invisiveis.

Nunca tive a mania de acompanhar as notícias da televisão. Até mesmo porque, sabia que o assunto era um só: a violência de todos os dias. Desligava a TV com dor de cabeça e com as mãos ensanguentadas. Mas agora era diferente... Não se falava tanto em crimes como se falava antes de a lei ser implantada. Tudo era calmo e tranquilo. Todos experimentavam uma paz sem igual. A vida seguia seu rumo silencioso, feliz, assustador e incomum. 
Um dia, acompanhando o noticiário por acaso, surpreendi-me ao reconhecer um certo rapaz. Ele era acusado de cometer um crime de assassinato e depois tentou se matar.

Aquilo foi uma novidade. Acredito que deveria haver dois ou três anos que não se falava em crimes de assassinatos. O fato foi chocante e todos ficaram meio perplexos com a crueldade do rapaz... Olhando os olhos dele brilhando na minha tela de resolução máxima, observei a tranquilidade com que falava e julguei que, talvez, não era a primeira vez que cometera tal atrocidade. Desliguei a TV e fui dormir.

No dia seguinte, acordei com a ideia fixa de que conhecia o rapaz da noite anterior. Fui ao trabalho e a agitação dos transplantes me fizeram esquecer o acontecido.

Mais seis meses se passaram... Estava eu no táxi, indo para o hospital. Meu carro havia quebrado na noite anterior e (não me perguntem como ou por que) não fazia a menor ideia do que tinha acontecido com ele. Mas... estava no táxi e ouvi uma reportagem dizendo que uma professora que fora operada recentemente assaltou um banco com extrema violência e crueldade, matando sete pessoas inocentes que ali estavam.

Alguns conhecidos da professora disseram que ela mudara bastante depois que soube que não iria mais morrer. A certeza de uma vida mais longa encheu-a de vontades que, quem a conhecia melhor, afirmava não serem caprichos dela... Parecia ser uma outra pessoa...

A agitação do dia a dia é suficiente para nos fazer esquecer as coisas. No entanto, quando cheguei a casa, liguei o aparelho e lá estava 
o noticiário detalhado, com as imagens dos mortos e da professora assassina. Por um instante, acreditei reconhecê-la, mas rapidamente desanuviei o pensamento e procurei não buscar ligações em coisas que só existiam em minha mente.

Ouvi uma boa música. Jantei. Descansei e fui dormir.

Os intervalos começaram a diminuir. Agora, três meses depois do caso da professora, surge uma história que deixou todos estupefatos.

Um homem com aproximadamente 42 anos de idade mantinha três crianças presas em sua casa e abusava delas todos os dias. As crianças (todas, meninas) tinham entre 10 e 13 anos de idade e seus pais eram pobres que viviam drogados o dia inteiro e nem lembravam que tinham filhas para criar.

O pedófilo fingia que cuidava das meninas... Dava um dinheiro para os pais e sumia com todas. Era uma coisa cruel, pois, após violentá-las por semanas seguidas, ele as matava e enterrava os corpos no quintal da própria casa. Como se estivesse se livrando de um animal qualquer.

O azar desse monstro foi ter sido visto agredindo uma criança desconhecida porque ela não queria entrar em sua casa. A vizinha, que não tinha nada melhor para fazer do que espionar a rua, viu a cena e ficou de butuca vigiando a entrada e a saída da casa do homem. Até que um dia, quando ele se descuidou e foi à cidade, ela viu pela janela as crianças amarradas dentro de casa e todas sujas de sangue.

Rapidamente, ela voltou e ligou para a polícia. Quando os policiais chegaram, o homem já havia voltado e foi pego assistindo 
televisão enquanto as crianças, deitadas no chão sujo da sala imunda, dormiam amarradas com uma corrente presa ao pescoço.

Esse fato chocou a todos. Ninguém entendia o porquê dessas crueldades. Todos ficamos perplexos com a frieza e a maldade dos depoimentos daquele homem que não tinha cara de pedófilo. Olhando pela TV em minha casa, percebia no cretino uma alegria por ter sido preso (ou por ter cometido tais crimes... não sei ao certo) e uma tristeza por não saber o que fazia... Pareceu-me que ele estava perdido e fora de si, como se fosse um autômato, um fantoche manipulado por uma força desconhecida qualquer.

Os casos aumentaram. Antes, demoravam meses para acontecer, mas, agora, toda semana, todo dia tinha uma história trágica e estranha acontecendo em algum canto da cidade. Novos pedófilos cultos surgiram. Homens de famílias aparentemente normais entravam nos shoppings e sacavam armas poderosíssimas. Atiravam à vontade, matando inocentes e culpados, crianças e velhos, homens e mulheres; personalidades conhecidas tanto no meio artístico como em outras áreas de nossa sociedade cometiam crimes que simplesmente deixavam todos preocupados com o rumo que as coisas estavam tomando. Tudo parecia fugir do controle.

III

Não sei exatamente onde ouvi alguém dizer que tudo havia começado sete meses depois de a tal lei da doação de órgãos ter entrado 
em vigor. Num primeiro momento, não liguei muito para o comentário. "Certamente, deve ser algum parente descontente com a situação", pensei. Mas a verdade é que essa ideia ficou-me martelando os pensamentos e cheguei a considerá-la por alguns dias, moendo e remoendo as diversas possibilidades de ela ser verdadeira.

A princípio, não queria acreditar no que comecei a ouvir nas rádios e a ver nos telejornais a que assistia. Um grupo de religiosos fanáticos dizia que tudo o que estava acontecendo era o final dos tempos. Todas as crueldades eram realizações das pragas apocalípticas e que ao homem pecador só caberia uma única saída, arrepender-se.

Lembro como se fosse hoje. Houve um frenesi na cidade. Em todos os cantos as pessoas pensavam em montar templos enormes para adorar a deuses. As religiões pipocaram em cada canto do mundo. Nos lugares mais recônditos e inabitados havia sempre um templo onde as pessoas se refugiavam de um Mal que elas não sabiam ao certo como tinha nascido.

Por outro lado, cientista, médico e racional que sou, tentei explicações que pudessem satisfazer meu senso de homem crítico e centrado. Busquei os motivos das mortes e das mudanças de comportamentos. Todas as pessoas envolvidas nos crimes brutais eram cidadãos comuns, bons, responsáveis e alguns com bastante prestígio social. Tinha de haver uma resposta para toda aquela situação estranha! Cogitei um envenenamento em massa, mas acredito que logo desisti de tal absurdo. Qual seria o objetivo desse ato irracional? ponderei. 
Buscando e não encontrando respostas, acabei voltando-me para a estúpida ideia da doação de órgãos. Recusei-me a aceitá-la, mas não encontrava respostas plausiveis para minhas perguntas e, diante dos fatos, comecei a pesquisar. Primeiro, fiz um levantamento das pessoas mais próximas e envolvidas nos crimes mais recentes. Depois, fui à prisão visitar aqueles que estavam vivos e entrevistá-los para sondar respostas ocultas em suas personalidades duplas (se é que se pode falar em dupla personalidade nesses casos).

Como me apresentava em nome do governo, eles me diziam quem havia feito a doação. Confesso que fiquei estarrecido ao constatar que todas as pessoas haviam recebido órgãos de criminosos. Entrevistei homens e mulheres que receberam órgãos de assassinos, pedófilos, estupradores, ladrões, prostitutas, políticos corruptos etc. A variedade era tão grande que saí de lá com a cabeça fervilhando de ideias com as quais lutava para aceitar.

Quando dei por mim, já passava das oito da noite... Fui para casa e, cansado como estava, nem comi nada. Deitei na cama e adormeci profundamente.

Ao acordar, as dúvidas vieram-me: Teria razão a frase que ouvi? Será que as pessoas, após receberem os órgãos, assimilam algumas características comportamentais do doador? Seria essa a explicação para a aparente tristeza do pedófilo ao ser preso? Ele não sabia o que havia acontecido? Havia uma vontade maior do que a dele nele? Haveria mais de um num só corpo? Essas dúvidas surgiram-me como relâmpagos na mente... Todavia, ao lado destas, outras mais surgiram: 
Será que, ao saber o doador, o receptor sente-se impressionado e por isso manifesta uma vontade que não é sua, mas do outro? Será que esta vontade realmente é do outro ou apenas estava adormecida em cada uma daquelas pessoas? Será que a raça humana não é tão humana quanto se pensou? E, por fim, será que dentro de nós há sempre um renascimento, mesmo quando não sabemos ou queremos?

Pensei e repensei, mas respostas não foram encontradas.

Tentei não ligar para o que estava acontecendo ao meu redor e esperei para ver se tudo se acalmaria novamente. Os dias, as semanas, os meses, os anos passaram-se e tudo foi emoldurando-se aos poucos ao padrão da vida comum como tem que ser. Os assaltos e os assassinatos não diminuíram. Casos de pedófilos e estupradores continuaram a aparecer pelos cantos da cidade. Mulheres jovens e velhas matavam seus maridos sem aparente explicação e lindas mulheres se prostituiam como profissionais que nunca foram.

Tudo parece que voltou ao normal.

Agora, enquanto vejo os novos acontecimentos, percebo que o tempo passa e, às vezes, pergunto-me por que as coisas são como são. Quem olha para mim hoje - depois de uma vida completamente entregue ao cumprimento do bem - não entende o porquê do meu recolhimento. Ando pelo pátio da prisão sem saber ao menos por que vim parar neste lugar. Tenho uma vaga lembrança de uma vida que tive antes da operação. Na verdade, não sou diferente de nenhum dos que estão aqui comigo. Mas, a grande questão que me persegue nesses meus dias nefastos e pesarosos é saber se a maior de minhas perguntas 
pode ser respondida: Quem está verdadeiramente preso, eu ou os que estão fora desses muros que se levantam diante de mim todas as manhãs? 